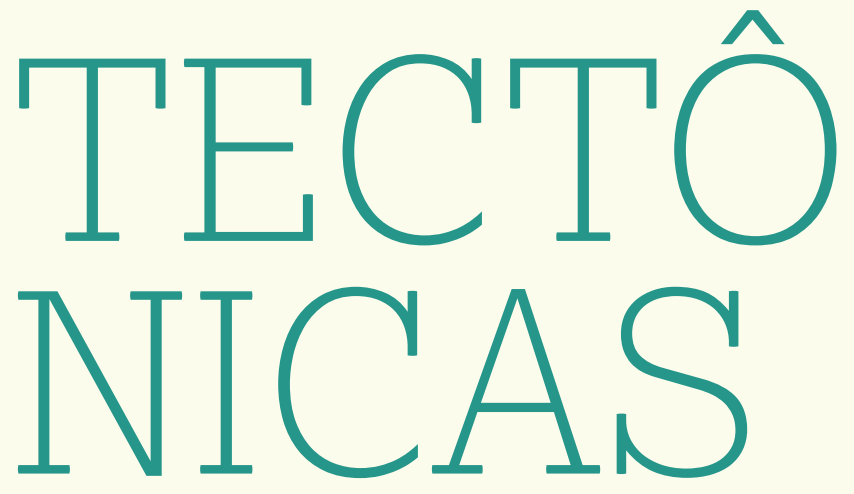

Do grego tektonikos, -ê, -ón. Arte de carpinteiro. Arte de construir edifícios. Estudo da estrutura da crosta terrestre. Placas tectônicas, criadas nas zonas de divergência, seu afastamento possibilita a explosão do magma. 



\title{
A FILOSOFIA DO MICTÓRIO - CONSIDERAÇÕES SOBRE O ROMANCE O CASAMENTO (1967), DE NELSON RODRIGUES
}

\author{
- JOÃO GABRIEL MOSTAZO LOPES
}

\section{RESUMO}

Este ensaio procura traçar, através da análise do romance O Casamento (1967), de Nelson Rodrigues, algumas linhas de força para pensar a existência de diferentes projetos de modernidade na literatura brasileira da primeira metade do século XX. A análise se concentra sobretudo no romance de Nelson Rodrigues, e aposta na obra do autor como representativa de um projeto distinto, e mesmo oposto, à tradição inaugurada sobretudo pelo Modernismo paulista. Para isso, procuramos ler o romance e as questões que ele levanta em comparação com o Manifesto Antropófago (1928) de Oswald de Andrade, lançando mão ainda, quando é conveniente à ampliação da discussão, de um atravessamento por conceitos da psicanálise lacaniana para pensar não apenas os dois autores em questão, mas a corrente de influências que as suas obras tiveram ao longo do século passado sobre a literatura e a cultura brasileiras.

Palavras-Chave: Nelson Rodrigues, Oswald de Andrade, antropofagia, carnaval, ritual, obsceno.

\section{ABSTRACT}

This essay tries to distinguish, by means of the analysis on the novel O Casamento (1967), by Nelson Rodrigues, some main traces in order to think the existence of different projects concerning the problem of Brazilian literature's modernity, by the first half of the 20th century. The analysis focus mainly on Rodrigues' novel, and claims that the authors work can be read as representative of a project which is distinct, and even opposite, to that of the tradition first launched by the modernist movement in São Paulo. To do so, we read the novel and the questions it rises in comparison to the Manifesto Antropófago (1928) by Oswald de Andrade, going through, when we feel it can widen the discussion, some concepts from Lacanian psychoanalysis, to think not only both authors, but the stream of influence that their works have had throughout the past century in Brazilian literature and culture.

Keywords: Nelson Rodrigues, Oswald de Andrade; anthropophagy, carnival, ritual, obscene. 


\section{BRASILEIRO E MODERNO}

1 m uma entrevista para o programa "Abertura", da Rede Tupi, em

— 1979, Plínio Marcos recebe a seguinte pergunta, supostamente enviada por Nelson Rodrigues: "por que você se considera o maior autor [de teatro] do Brasil?". A resposta de Plínio Marcos, de bate-pronto, esclarece em alguma medida a posição que o autor de $O$ beijo no Asfalto ocupava já à época no cenário da literatura e do teatro brasileiro modernos: "Porque eu copio os seus defeitos, Nelson Rodrigues".

Esse tipo de reação certeira por parte de Plínio provavelmente é um desdobramento do fato de que Nelson Rodrigues era, e ainda é para muitos, tido como o pai no teatro brasileiro moderno, e que, nessa condição, impõe efetivamente um problema, no melhor sentido, para qualquer autor que o suceda. O problema da modernidade da obra rodrigueana, no que se refere não apenas à sua dramaturgia mas também ao seu trabalho como prosador, em romances e crônicas, no entanto, gera uma questão de dupla ordem: em que sentido, exatamente, Nelson Rodrigues é um autor moderno? E de que maneira podemos falar, no seu caso, de uma modernidade brasileira? Se indicaremos rapidamente aqui, por um lado, que a sua modernidade é algo ambivalente - mas não é essa a característica de toda a modernidade literária, de Joyce (que sentia como seus contemporâneos mais próximos Dante e Shakespeare) a Eliot e Pound? -, não obstante o esforço interpretativo, por ora, será o da exploração da segunda parte da questão: como a obra rodrigueana se insere na tradição da literatura brasileira moderna? Para adiantar a questão, sugiro que esse problema se permite pensar através da relação negativa entre Nelson e o projeto literário da Antropofagia oswaldiana, cujo desdobramento, no âmbito teatral, se projeta sobre o embate entre o teatro rodrigueano e o teatro francamente antropofágico-tropicalista de José Celso Martinez Corrêa, à frente do Oficina. Não interessam, por outro lado e ao menos imediatamente, as diferenças formais entre a dramaturgia e o romance; elas se apagarão na medida em que a relação entre a forma, seja ela qual for, e aquilo que chamo de "a filosofia do mictório", que se percebe mais claramente no romance O Casamento, de 1967, serve, no interior da obra do autor, como uma espécie de arte poética, que pode ser aplicada na interpretação, também, da sua dramaturgia. Dito de outro modo, quem nos interessa aqui não é o Nelson romancista ou dramaturgo, mas o Nelson autor, sem ignorar algumas generalizações nas quais essa noção implica. 


\section{DIZER VS. DEGLUTIR}

“- Meu filho, deve-se dizer tudo, exatamente tudo.

Sabino teve medo. "Tudo" menos as fezes do pai. Não diria que, desde de manhã, só pensava na morte do pai. No casamento da filha e na morte do pai. Sentia, por toda a cidade, o cheiro de sangue e urina que há em toda agonia.

Monsenhor dizia:

- O que não se diz apodrece em nós"

(RODRIGUES, 2002, p. 171)

Perguntei a um homem o que era o Direito. Ele me respondeu que era a garantia do exercício da possibilidade. Esse homem chama-se Galli Mathias. Comi-o.

(ANDRADE, 2001)

Alinhando-se a uma determinada narrativa sobre a literatura brasileira, pode-se dizer que o Manifesto Antropófago escrito por Oswald de Andrade em 1928 é, mais do que um ponto de inflexão na narrativa do modernismo paulista, um dos paradigmas da literatura brasileira moderna. A sua influência sobre a cultura nacional nas décadas seguintes se sente sobretudo nas obras de alguns compositores populares a partir dos anos 1960, mas também em poetas como Ferreira Gullar, Chacal e Chico Alvim, na Poesia Concreta, nas instalações de Hélio Oiticica, na antropologia de Eduardo Viveiros de Castro e no teatro paródico e carnavalesco-ritualístico de José Celso Martinez Corrêa. A obra oswaldiana elabora pela primeira vez o "axioma da deglutição", caro ao pensamento artístico brasileiro sobretudo na segunda metade do século XX.

O Manifesto, publicado originalmente no primeiro número da $R e$ vista de Antropofagia, em maio de 1928, termina assinado: "Oswald de Andrade, em Piratininga, Ano 374 da Deglutição do Bispo Sardinha”. A ideia - que mais tarde ganharia contornos sociológicos e historiográficos nos escritos de Gilberto Freyre e Sérgio Buarque de Hollanda seria a de que aquilo que, até fins do XIX, era percebido como o grande entrave para a modernização da nação - a miscigenação e a presença de certo "arcaísmo" no Brasil às portas da modernidade industrial e urbanizada - seria na verdade o núcleo mesmo da modernidade brasileira e da particularidade da nação. Em Oswald, essa ideia está na base do projeto estético da assimilação de todas as culturas que participaram na formação da cultura brasileira, em especial o pensamento selvagem-indígena, bem como das novidades das artes de vanguarda 
que apareciam na Europa. Pode-se dizer com Antônio Cândido que, dialeticamente, o projeto vanguardista de modernização europeu só se realiza plenamente no Brasil, onde o Moderno e o Arcaico permanecem irredutivelmente enroscados ${ }^{1}$.

A princípio, nada mais distante do sentimento de purgação que a obra rodrigueana parece respirar. As premissas de todo esse raciocínio parecem mesmo formar o caldo cultural contra o qual a obra de Nelson Rodrigues se projeta, e seria possível argumentar inclusive que essa é uma das razões pelas quais a assimilação da sua obra foi, em larga medida, retardada por parte de certa ala da esquerda cuja atuação se desdobrou ao longo do período da ditadura militar, e que lia no autor um indesculpável reacionarismo ${ }^{2}$. Em O Casamento, o protagonista Sabino busca conselhos morais e práticos junto à figura grotesca do Monsenhor, um padre "vasco e gigantesco", de voz grossa, articulador de um catolicismo herege e persuasivo, capaz de afirmar, por exemplo, ser apenas nos atos da evacuação da bexiga e do intestino que se está verdadeiramente próximo de Deus. A magreza canalha de Sabino, os seus suores constantes, e - o que interessa particularmente a nós - a sua incapacidade de se alimentar ao longo do romance encontram no Monsenhor uma formulação com força e ares de manifesto, disperso em frases que se repetem ao longo das reuniões entre os dois personagens, a primeira delas, significativamente, no mictório da igreja.

E no entanto, se o "deglutir tudo" oswaldiano não é, ao contrário do que parecem sugerir algumas leituras, um banquete irrestrito e, no limite, acrítico - se o apetite do antropógafo é, em realidade, ao mesmo tempo voraz e rigoroso; carnavalesco e cirúrgico - o mesmo se pode dizer da "filosofia do mictório": o seu mote, "dizer tudo", longe de se pretender uma ferramenta de apreensão direta e imediata da realidade, pressupõe o interdito. Há, entre os dois projetos, uma correspondência formal que diz respeito aos efeitos que a intuição de um centro vazio no interior da ideia de Absoluto provocam - notadamente o de acolher, no último, este vazio como fundamento do próprio projeto. O dizer tudo surge assim

[1] "As terriveis ousadias de um Picasso, um Brancusi, um Max Jacob, um Tristan Tzara, eram, no fundo, mais coerentes com a nossa herança cultural do que com a deles" (CÂNDIDO, 1999, p. 127).

[2] Lembremos uma afirmação de Antônio Abujamra sobre o autor: "[...] ele sempre foi odiado pelo público, era considerado pornográfico, um grande reacionário - o que ele mesmo achava - e agora a gente está vendo que ele não era um grande reacionário. [...] Ele faz a tragédia do cotidiano virar comédia; ele faz a comédia do cotidiano virar tragédia" (trecho dito durante programa na Rádio Cultura, por ocasião dos dez anos da morte de Nelson Rodrigues). 
no instante em que a impossibilidade de dizer certas coisas (as fezes do pai) é mais traumática. Segue-se que a linguagem do romance vaza em uma série de excessos insuportáveis que, porque podres, precisam ser expelidos (ou formulados). Assim é com a palavra "masturbação", que o Monsenhor insiste em repetir, quando Sabino prefere o eufemismo "onanismo"; assim são com os suores, mijos, sêmens, secreções, odores e principalmente vômitos que figuram ao longo de toda a obra.

\section{OBSCENO VS. RITUAL}

"No fundo do mar há imensas florestas menstruadas"

(RodRIGUes, 2002, p. 204)

No caso de $O$ casamento, o lugar de onde surgem as secreções e as palavras que vazam para fora do corpo e para dentro do romance é o do obsceno. O próprio romance se encarrega de ilustrar essa espécie de inconsciente da palavra-corpo com cômica sordidez no capítulo 23. A esta altura do romance, Sabino e a filha Glorinha encontram-se em uma praia, no início da noite. Imediatamente antes, ela havia dito, ainda no carro, no final do capítulo anterior, que detestava a própria mãe. O capítulo seguinte abre, portanto, com a indignação do pai diante da afirmação, ao que Glorinha responde: "Ah, o senhor não me entende, papai! Não é isso. Nas nossas conversas eu sinto, sabe? Sinto que o senhor não diz tudo. Nunca diz tudo". Sabino então interpela Glorinha, exigindo saber os motivos que a levaram a dizer tais impropérios sobre a mãe. Com cruel ironia, a moça promete que irá dizer tudo, mas antes, quer ir à praia. Sabino tenta encontrar palavras para demonstrar sua fúria, mas emudece. Contrariado, ele obedece. A cena assume, então, os contornos de uma travessura adolescente banal. Sabino se espanta diante da irreverência com a qual Glorinha tira os sapatos e corre em direção ao mar, e põe-se a segui-la, fantasiando com a possibilidade de um assalto noturno (é importante notar que, a esta altura, o leitor já tem a dimensão do significado erótico que os pés têm para Sabino, o que irá reverberar diante dos pés da filha, e mais ainda quando ela ordena, em seguida, que ele também tire os sapatos). Abruptamente, no entanto, a cena é atravessada por uma série de imagens obscenas, posicionadas numa zona de indeterminação entre a voz do narrador e o monólogo interno do protagonista, que Sabino adivinha enquanto caminha sobre a areia: "O mar cheira a esperma, urina velha, sexo mal lavado. Lá longe, estava uma ilha só de pedra. E a ilha não tinha uma flor, um fruto, uma 
fonte - só tinha cocô de gaivota"3. É o primeiro indício de que algo, por baixo da cena cotidiana e até inocente da travessura entre pai e filha, está inquieto. Mais: as imagens, que irrompem para dentro do texto inadvertidamente, não apenas ameaçam a estabilidade da cena - que em verdade já não existe -, como sugerem que a própria quebra dessa estabilidade (que já fora rompida pela fúria do pai), não passava de um mero desajuste previsível, e mesmo remediável, fossem outras as circunstâncias. O que essas primeiras imagens anunciam é que, no fim das contas, em vista do que está prestes a ocorrer, a explosão paterna diante da prova de desamor que a filha oferecera ficará distante, e mesmo irrelevante. Algo muito maior se move sob a superfície.

A cena segue. Glorinha desafia a fúria anteriormente demonstrada pelo pai com uma pergunta simples, mas profundamente cruel e ambígua: "O senhor gosta de mim?". Sabino responde que sim, é claro, e se enrola todo, dizendo que gosta de Glorinha muito mais do que ela mesma pensa. Ele se cala 4 . "E entre mim e mamãe?". Sabino tenta sair pela tangente, evocando a diferença irredutível entre esposa e filha, e tenta ainda assumir uma posição de vítima da situação, sugerindo que Glorinha deseja magoá-lo. Rapidamente outra imagem inusitada se instala, reforçando o jogo de súbitas erupções poético-obscenas, que marcam os momentos decisivos nos quais a consciência de Sabino é testada às últimas consequências: "Sabino pensa que no fundo do mar, muito no fundo do mar, há imensas florestas menstruadas". Glorinha continua, impiedosa: "Papai, posso dizer tudo?”. Sabino faz que sim, e treme. “... o frio parece torná-lo mais magro. Todos os seus ossos estão doendo", diz o narrador. É contra esse homem amedrontado, reduzido ao próprio esqueleto - contra essa essência dura de homem, reduzido aos problemas duros e às perguntas essenciais - que Glorinha lança: "E se eu não me casasse amanhã?". Sabino se desconcerta. Agarrando o pai pelo braço, "quase boca com boca", Glorinha diz tudo: odeia a própria mãe, odeia as irmãs, e não gosta do noivo. Tem-se aqui uma terceira irrupção imagética, e perceba-se como, a cada vez que a operação é repetida, ela

[3] Note-se que, para o efeito alcançado por essas irrupções, a forma romance se presta mais que a forma dramática, por conta da figura sempre ambígua do narrador onisciente. Nesse sentido, se a operação aqui posta em jogo se repete em diversas peças do autor escritas para o teatro, em O Casamento ela alcança uma amplitude de outra ordem.

[4] Diga-se de passagem que a quantidade de vezes que Sabino se cala, emudece, engasga e tropeça nas próprias palavras, e o uso repetido de reticências, para as suas falas, são também sintoma do descompasso entre o imperativo do "tudo dizer" e a impossibilidade de dizer tudo - ou de dizer certas coisas. 
ganha contornos mais concretos, aproximando-se da cena e interferindo diretamente na maneira como Sabino percebe o seu universo mais concreto e material - como se a palavra assumisse, para o desespero e confusão de Sabino, cada vez mais corporeidade: "Glorinha tem hálito de esperma". Ele tenta repelir a linguagem obscena de volta para longe, mas ela retorna, mais poderosa: "Não é Glorinha. É o mar. O mar que cheira a certos corrimentos vaginais". Com uma concisão de verso, essas três frases estabelecem com precisão o movimento de todo o capítulo e, de uma certa maneira, de todo o romance: uma enorme dimensão do corpo da linguagem, no qual repousam certas coisas que foram negadas pela realidade cotidiana das personagens, retorna e desmantela a sua aparente estabilidade simbólica.

A cena avança então, anunciando, se o leitor já estiver completamente identificado com a posição de Sabino - mas é exatamente sobre essa identificação que a cena irá saltar abruptamente, ao final - uma tragédia ou um melodrama familiar: Glorinha deita a cabeça sobre o colo do pai e revela que "gosta de quem não podia gostar". Ele pergunta quem é. Ela se nega a dizer. Sabino reforça que a filha pode, mais uma vez, "dizer tudo" a ele. Ao que ela responde, sádica: "Por que é que eu hei de dizer tudo, se o senhor não diz nada? O senhor tem medo, medo!”. Sabino gagueja. A filha exige saber se Sabino gosta da esposa. Ele admite que não. Sabino já está, aqui, de quatro na areia, sendo chamado de covarde, absolutamente derrotado, ao ponto significativo em que já "não reconhece a própria voz". O processo de humilhação e a tensão à qual a sua consciência moral está submetida são tamanhos que o sujeito se torna um estranho para si mesmo, um outro. É só então, diante desse outro, que Glorinha pode revelar que o motivo pelo qual detesta a mãe remonta a um abuso sexual, na infância. Mais precisamente, um beijo de língua, num certo dia, no banheiro, depois do banho. Sabino vai à loucura, e ameaça bater na filha. Ela desafia. Ele recua, e se afasta, repetindo consigo que é "católico praticante", numa tentativa de retornar a si mesmo - ou antes à imagem que tem de si mesmo, como um respeitável chefe de família, cristão, imune às imensas florestas menstruadas e ao cheiro de esperma e de corrimentos vaginais. Incidentalmente, esse não é o único momento do romance em que Sabino "sai de si". Se, aqui, o outro aparece por estranhamento, por diferença, seria possível argumentar que os repetidos vômitos diante do Monsenhor, em outras passagens, são uma espécie de "tornar-se outro" por subtração, por tirar algo de dentro de si, ou que ainda a imagem recorrente das fezes do pai, no leito de morte, também conturbam essa autoimagem que Sabino faz de si mesmo, de "bom filho". De todo modo, está claro que uma chave operativa fundamental no 
romance é a do descompasso entre a realidade simbólica das personagens - o marido, a esposa, o pai, a filha, o filho, o patrão, a secretária, o amante, o padre, o fiel etc - e uma camada misteriosa, subterrânea, como um magma sob a superfície do romance, em constante ebulição, constantemente negada pelo primeiro plano. Algo muito próximo da ideia de Real ${ }^{5}$ na psicanálise, embora não seja o caso, aqui, de entrar em águas lacanianas. Limitemo-nos a notar que é na experiência de despossessão de si que o Sujeito se encontra com esse Real traumático, que Sabino experimenta angustiadamente como um Eu insuportavelmente mais "real" que o seu "verdadeiro" $\mathrm{Eu}^{6}$.

Aproximando-se do final, a paranoia de Sabino irradia por todo o espaço subjetivo da cena. Ele se pergunta se não fora a filha que se despira diante do Monsenhor, retomando uma passagem de alguns capítulos antes, na qual o padre confessava que uma jovem havia se oferecido a ele, mas se negava a lhe revelar a identidade, plantando a semente que agora se apodera da consciência de Sabino. Ela oferece um último "dizer tudo", então, e pergunta se o pai não gostaria de saber de quem é que ela realmente gosta. Mas a tragédia suprema de Sabino é que, neste ponto, ele já não precisa mais que se diga tudo. Ele já tem todas as certezas de que precisa, já montou todo o quebra-cabeças. Sabino recusa a oferta, e diz, então, que ele também gosta de alguém de quem não pode gostar - uma pessoa que deveria ser "sagrada" para ele. A filha - num momento de inocência que eleva a tragédia à última potência - pergunta, simplesmente, como se não estivesse participando da cena até então, nem estivesse ela mesma manobrando o jogo o tempo inteiro: "Quem?". "Sabino agarra a menina. Dá-lhe um violento beijo na boca". Para o desespero de Sabino, Glorinha se desprende do pai, e se afasta. "A menina passa a mão na boca: - Não foi beijo de pai!”. A partir daí, a queda moral de Sabino é vertiginosa, e o desmantelamento do cenário montado por ele está consumado em meia página de acusações impiedosas por parte de Glorinha, que terminam com: "Eu sempre

[5] Por Real entendemos, aqui, "não um conjunto firme de oposições simbólicas 'estáticas' e de exclusões/inclusões, [...] mas o nome de um impasse, de um trauma, de uma questão em aberto, de algo que resiste a toda tentativa de simbolização", na formulação precisa de Slavoj Zizek (Zızek, 2010). Note-se ainda que, no caso do capítulo em questão, uma outra dimensão fundamental do Real pode ser demonstrada, precisamente na insistência com que essas imagens irrompem para dentro do espaço simbólico de Sabino, a despeito da tentativa de afastá-las: a sua ambivalência constitutiva, ao mesmo tempo impossível e inevitável/incontornável.

[6] Há uma correlação formal entre as ideias de Trauma e de Real, no sentido de que, se o trauma se refere a algo que precisa ser negado (ou recalcado) pelo inconsciente para que o sujeito possa perceber-se a si mesmo como uma unidade, o Real é justamente, para Lacan, aquilo que deve ser negado para que a realidade (formada pelo compêndio Simbólico-Imaginário) apareça como um Todo coerente. 
achei que o seu amor por mim não era normal”. Ao final, diz o narrador: "Noite escura, não se vê mais a ilha, ilha toda feita de pedra e de cocô de gaivota". O espetáculo se fecha - como as cortinas de um teatro. A ilha não pode mais ser vista. Mas ainda está ali.

A diferença ontológica entre a abordagem rodrigueana e, para retomar o ponto central, a Antropofagia, é evidente. Se, na linhagem inaugurada por Oswald de Andrade, o aumentamento era alcançado através da deglutição/assimilação, em Nelson Rodrigues o movimento é o contrário: mira-se uma redução, através de uma série de operações de vazamento. Esse vazamento está presente em todos os níveis do romance: no enredo, nos constantes suores, vômitos e secreções expelidas pelas personagens; e na linguagem, como vimos, através da irrupção do obsceno no interior da cena. A relação forma-conteúdo que essas irrupções articulam, no capítulo em questão, por exemplo, revela o dispositivo na sua operação mais dinâmica, e nos autoriza a falar dele como o motor formal da obra. Se, no Manifesto Antropófago, Oswald de Andrade celebrava o ritual de devoração do bispo Sardinha, lançando as bases para a elaboração de uma poética que tivesse como elemento fundamental o potencial profanador ("transformar o tabu em totem") do carnaval e da subversão de todo o mistério, a poética rodrigueana se projeta radicalmente no sentido inverso, filiando-se precisamente ao mistério, e articulando uma série de desmantelamentos da realidade simbólica pelo contato com essa dimensão interdita, sem, no entanto, totemizá-la. Daí uma série de termos opositivos que podemos sugerir para tatear as diferenças entre os dois autores - mais, entre duas tradições distintas de se pensar o Brasil e a modernidade: se por exemplo, para o antropófago, o que interessa é o selvagem, para além (ou aquém) da civilização, a filosofia do mictório professa o interdito da civilização; contra o carnaval, a conversão herege ${ }^{7}$; contra a Comédia, a Tragédia; contra a leveza, a gravidade, e contra a farsa pagã, a purificação cristã da culpa, e o seu fracasso.

[7] A heresia, aqui, longe de ser uma negação do cristianismo, funciona, dialeticamente, como o seu suplemento Real, se pensarmos como Fredric Jameson que a blasfêmia "não só exige que tenhamos uma forte percepção da qualidade sagrada do nome divino, mas pode até mesmo ser vista como uma espécie de ritual por meio do qual essa força é reacionada e revitalizada" (JAMESon, 2006, p. 62). Pense-se ainda na quantidade de hereges que, posteriormente, foram canonizados pela Igreja, ao longo dos séculos. 


\title{
4. EXPIAÇÃO VS. SACRIFÍCIO
}

\author{
Tal como infantes vergonhoso, mudos \\ de olhar no chão a censura escutando, \\ e lamentando os erros seus miúdos, \\ tal estava eu, quando ela disse: "Quando \\ o que ouças te doer, levanta a barba, \\ e mais desgosto colherás olhando". \\ [...] pela "barba" ao pedir o meu olhar, \\ constatei o veneno do argumento.
}

(DANTE, "Purgatório", canto 31, v. 64-68; 2000, p. 72-73)

Às portas do Paraíso, prestes a banhar-se nas águas do rio Lete, Dante enfrenta uma última provação, levada a cabo por Beatriz. Nessa passagem, do canto 31 do Purgatório, o poeta é submetido a um processo de humilhação purificadora, através do qual completará o ritual de expiação da culpa necessário para a entrada no domínio da inocência divina. Após exigir de Dante a confissão dos seus pecados, Beatriz volta-se para o poeta e o repreende veementemente pela displicência com a qual ele teria "baixados as asas" (v. 58) e se resignado a vaidades "de uso limitado" e outros "golpes de ventura incerta" (v. 59-60), depois da morte prematura da musa, anos antes. A humilhação final vem quando Beatriz ordena "venenosamente" que Dante, agora constrangido como uma criança mal-educada, "erga a barba" e a olhe nos olhos ${ }^{8}$.

A figura de Dante infantilizado e repreendido, às margens do Lete, lembra a de Sabino, na praia, diante da filha. A comicidade dos últimos parágrafos do capítulo 23 do romance de Nelson Rodrigues ecoam o desconcerto e a humilhação de Dante diante de Beatriz:

Tropeçou nas próprias pernas e caiu. Primeiro, ficou de gatinhas e, depois, deitou-se de bruços. Certa vez, Eudóxia dissera: 'Se houver um concurso de bunda, o primeiro lugar, fácil, é de Glorinha'. Na noite escura, não se vê mais a ilha, ilha toda feita de pedra e de cocô de gaivota. 
Ele está chorando:

- Glorinha não entendeu. Eu não sou incestuoso. Eu não desejaria a minha própria filha.

(RODRIGUES, 2002, p. 208)

Ao contrário da Divina Comédia, no entanto, não há, ao menos à primeira vista, redenção em O Casamento. Se, em Dante, como sugere Agamben, a humilhação é um dispositivo articulado com o objetivo de interromper a pulsão trágica da experiência erótica ${ }^{9}$, e reorientar o eixo do problema da culpa da Natureza para a Pessoa - e portanto da Tragédia para a Comédia -, o elemento trágico em Nelson Rodrigues reside exatamente na incompletude dessa operação de purgação. Temos o pecado (o desejo pela própria filha, e o beijo) e a humilhação (tanto nas palavras avassaladoras de Glorinha quanto da postura patética em que Sabino se encontra, ao final da cena) mas a possibilidade de que se formulem o arrependimento e a confissão permanece restrita à manifestação oblíqua da pura negação: "Eu não sou incestuoso. Eu não desejaria a minha própria filha", são as palavras finais do pai, às quais escutamos desconfiados. Sabino aproxima-se então de um estranho híbrido entre herói trágico e cômico - nem tanto um nem tanto outro: ele não tem a força do herói trágico clássico, que, como Édipo, arranca os próprios olhos para excluir à vista a própria vergonha ${ }^{10}$, mas ao mesmo tempo não encontra a redenção que o herói cômico por excelência - Dante - encontra, ao final da jornada. Nesse sentido, podemos vislumbrar a possibilidade de tangenciar o problema da modernidade de Nelson Rodrigues por essa via turbulenta, mas interessante: Sabino é um moderno precisamente no sentido em que não é nem trágico nem cômico - é ambos, e é nenhum. Algo parecido ocorre - de modo bastante distinto, é claro - com os heróis de Kafka, embora ali a chave penda (se é que pende) para a comicidade,

[9] "Na teoria do amor descrita por Virgílio no Canto 28 do Purgatório, a experiência erótica deixa de ser um conflito "trágico" entre inocência pessoal e culpa natural, e se torna uma cômica reconciliação entre inocência natural e culpa pessoal. [...] Essa passagem da culpa natural - trágica - para a culpa pessoal - cômica - é articulada através da teoria de Dante sobre a vergonha" (AGAMBEN, 1999, p. 15).

[10] É discutível se a rendição de Sabino, no final do romance, à polícia, é comparável ao gesto trágico, num sentido mais rigoroso. 
enquanto, no caso de Nelson, ela pende (certamente) para a tragédia ${ }^{11}$.

Podemos ler a afirmação de Abujamra, citada acima, à luz desse mecanismo, agora: "Ele [N.R.] faz a tragédia do cotidiano virar comédia; ele faz a comédia do cotidiano virar tragédia". Não é um simples jogo de inversões. Com um acento inegavelmente grave, o que se mantém constante é justamente o cotidiano: não há espaço para transcendência, não há possibilidade de redenção. Por mais que o próprio Nelson Rodrigues dissesse, em várias ocasiões, que encarava o teatro como uma experiência religiosa, a sua obra, objetivamente, aponta para o sentido contrário. Ao menos, essa é uma religião moderna, no sentido do seu desencantamento. É a religião, se assim se quiser, na qual Deus está mais próximo da bexiga e dos intestinos que do coração, e cujo templo é o mictório. "Sabino, quando eu mijo eu me sinto um jumento", diz o Monsenhor, e repete: "Mijo bonito como os jumentos" (RodRigues, 2002, p. 49).

Tudo isso é bastante distante da devoração ritualística do bispo Sardinha. Se, para o antropófago, o centro em torno do qual uma ontologia particular se constrói é o sacrifício do pontífice, aqui estamos mais próximos da operação expiatória da vergonha e da humilhação, da transferência da culpa - do vazamento do Real, em oposição à inversão carnavalesca do Simbólico, para pôr novamente a questão em termos lacanianos.

\section{LITURGIA E CARNAVAL}

Antropofagia. Absorção do inimigo sacro. Para transformá-lo em totem. A humana aventura. A terrena finalidade.

[...]

Nunca fomos catequizados. Fizemos foi o Carnaval. O índio vestido

\footnotetext{
[11] Também é possível formular essa distinção entre a determinação e a indeterminação do sujeito como a parte constitutiva do próprio sujeito moderno, dividido entre a particularidade do seu papel objetivo no interior de um determinado complexo de coordenadas simbólicas e imaginárias (pai, filho, padre, marido, amante - mas também brasileiro, patrão, homem, heterossexual, herói trágico, católico etc) e a universalidade da sua indeterminação constitutiva. Talvez a ideia de Sujeito dividido de Lacan (\$) remonte precisamente a essa dimensão que o sujeito moderno experimenta, de não ser mais capaz de identificar-se completamente com o papel que ele representa dentro, digamos, de uma sociedade - o que explica porque a angústia de retornar rapidamente para um terreno simbólico seguro, seja ele já conhecido ou não, seja tão presente hoje. Para o nosso contexto, talvez isso indique ainda porque a ideia que orienta o pensamento brasileiro moderno hegemônico, ao menos no nível da sua apropriação por dispositivos ideológicos de identificação nacional (isso é, a ideia de que a nossa indeterminação enquanto nação é a nossa particularidade nacional) não é uma ideia dialética, mas apenas uma reorientação regressiva do problema da indeterminação do sujeito moderno do campo da universalidade de volta para o campo das particularidades simbólicas (no caso, a particularidade do ser brasileiro). Diga-se de passagem, o papel central que tem aqui certo afeto pelo arcaísmo constitutivo das nossas instituições não deve ser menosprezado.
} 
de senador do Império. Fingindo de Pitt. Ou figurando nas óperas de Alencar cheio de bons sentimentos portugueses.

(ANDRADE, 2001)

Nesse sentido, embora haja uma atmosfera eminentemente místico-religiosa, tensionada por um vetor certamente não-ortodoxo, não há no romance a celebração de uma liturgia. O momento em que isso se torna mais concreto é, evidentemente, na recusa do Monsenhor em celebrar o sermão do casamento de Glorinha, no capítulo 28:

- Sabino, vim aqui para te dizer o seguinte: não vou fazer sermão nenhum.

Sabino exagera:

- Mas o que é isso, não faça isso. Eudóxia vai ficar inconsolável, monsenhor. E eu mesmo, compreende?

O padre coça a cabeça:

- Escuta, escuta. [...] O discurso que eu fizesse seria incendiário, subversivo.

- Subversivo como? O senhor quer dizer político?

O outro ria com sarcasmo feroz:

- Político? Ah, nunca! Para mim, política não é nada. É zero. Espera, espera. Você tocou num assunto que me interessa muito. Por exemplo: o crime político. Um César apunhalado é fósforo apagado. O falso patético, percebeu?

Então impulsivamente, Sabino o interrompe:

- Monsenhor, uma pergunta, uma pergunta.

Continua, rouco de desespero:

- Qual é mais importante, na sua opinião, o assassinato de César ou o defloramento de uma epiléptica? Sim, de uma epiléptica durante o ataque.

- Como? Não entendi. Fale outra vez.

Sabino repete, e acrescenta:

- Ainda mais tratando-se de uma menina de treze anos?

Monsenhor diz, gravemente:

- A comparação é boa, é boa. Eu fico com o defloramento. E veja você como, no confronto, o assassinato de César fica reles, ordinário, de quinta classe.

(RodRIGUes, 2002, p. 248-249)

Depois que o Monsenhor anuncia que não irá celebrar o casamento, o eixo da conversa muda rapidamente, precipitando-se por uma espiral vertiginosa que atravessa o assassinato de César e termina caindo sobre 
um dos traumas de Sabino, isso é, ter ele deflorado a sobrinha epiléptica durante um ataque. Já estamos nos últimos capítulos do romance, e é justo dizer que Sabino, de certa forma, "apreendeu" o funcionamento do universo dentro do qual está. Isso é, depois do episódio traumático da humilhação sem expiação na praia (cap. 23), aqui é o próprio Sabino quem "diz tudo", antes do Monsenhor. É uma inversão da dinâmica entre os dois personagens, que usualmente, ao longo do romance, consiste no Monsenhor funcionando como o operador da irrupção deste Real traumático (lembremos da cena em que o padre praticamente obriga Sabino a vomitar), e em Sabino sofrendo esse processo, indefeso. Aqui, é como se Sabino descobrisse o funcionamento dessa dinâmica e a antecipasse. O resultado é a cumplicidade, simplesmente, do Monsenhor, que passará então a desenvolver a sua teoria sobre os noivos terem de "unir as suas chagas" - revelando ser este o tema do sermão que ele não realizará - e, logo em seguida, admitirá que desistiu do sermão quando lhe ocorreu que, na verdade, os noivos só estariam pensando no "coito de logo mais". A sacada aqui é muito singela: não é o conteúdo do sermão que é inútil - visto que o Monsenhor praticamente o realiza, em particular, para Sabino; inútil é a cerimônia. O que é rejeitado pelo Monsenhor é a forma da liturgia - não o seu conteúdo, que, pelo contrário, é constantemente reafirmado, como uma espécie de arte poética final do romance: “Todos nós somos leprosos! E não há exceção. Nenhuma, nenhuma. Somos leprosos. [...] Assuma a sua lepra. E não a renegue, nunca! É a sua ressurreição, homem!”, diz o Monsenhor, se despedindo de Sabino pela última vez. A sabedoria do Monsenhor está na descoberta de que o "dizer tudo" é incompatível com qualquer estrutura simbólica pré-determinada, e em reconhecer a limitação da celebração litúrgica para este fim. O dizer tudo como o Real (lembremos que uma das suas definições é o "ponto de impossibilidade da formalização") não tem lugar dentro do universo simbólico determinado da liturgia cristã, do casório, da missa - nem mesmo da história, da política, da moral ("Eu fico com o defloramento!"). Como se o Monsenhor adquirisse, neste ponto, uma consciência extra-narrativa - como se ele tivesse observado de perto a jornada de Sabino, como se tivesse presenciado a sua humilhação trágica e desnecessária na praia - ele nega todo ritual e toda celebração (não é preciso dizer que o carnaval antropófago ou a celebração dionisíaca do Oficina passam a léguas deste ponto) como via de acesso para a ressurreição: a redenção transfere-se novamente para o plano subjetivo, mas, dessa vez, não-mediado por qualquer prática litúrgica, seja o sermão, seja a expiação dantesca - ambas liturgias determinadas eminentemente pelo discurso e pela sua realização em ato. Se, na liturgia, 
ato e discurso são uma e a mesma coisa ${ }^{12}$, o que o Monsenhor sugere, ao final, é a reorientação da dimensão litúrgica do discurso para o da ação direta - o que implica, consequentemente, na desativação do dispositivo litúrgico de um só golpe. "Assuma a sua lepra!": a ordem pode sem problemas estar inscrita em um plano discursivo, no sentido simples e amplo de que é dita; no entanto, ela não se realiza imediatamente, não porque é adiada, mas porque, no nível do sujeito, é impossível. Nela, discurso e ato estão novamente cindidos, devido à emergência de um colateral simbólico no interior da forma artística. É uma curva dramática impressionante para uma personagem que iniciou o seu sofismo herege no mictório do confessionário. I 
JOÃO GABRIEL MOSTAZO LOPES - Bacharel em Estudos Literários pelo Instituto de Estudos da Linguagem-IEL da Unicamp, e aluno do programa de Mestrado no Departamento de Teoria Literária e Literatura Comparada da FFLCH/USP. Endereço eletrônico para contato: j.mostazolopes@gmail.com 


\section{REFERÊNCIAS}

AGAMBEN, Giorgio. Opus dei, ed. Boitempo, São Paulo, 2010.

The End of the Poem, Stanford University Press, 1999.

ALIGHIERI, Dante. A Divina Comédia, trad. Ítalo Eugênio Mauro, ed. 34, São

Paulo, 2000.

ANDRADE, Oswald. Manifesto Antropófago, in. Obras Completas de Oswald de Andrade, ed. Globo, Rio de Janeiro, 2001.

CÂNDIDO, Antonio. Literatura e sociedade, PubliFolha, São Paulo, 1999.

JAMESON, Fredric. O inconsciente político, ed. Ática, São Paulo, 2006.

RODRIGUES, Nelson. O Casamento, Companhia das Letras, São Paulo, 2002.

ZIZEK, Slavoj. "Deleuze and the Lacanian Real” in: The Symptom 11 (Spring), 2010. Disponível em: http://www.lacan.com/zizrealac.htm. 
